\title{
PENGARUH WORK FAMILY CONFLICT TERHADAP STRES KERJA DAN KINERJA WANITA PERAWAT DI RUMAH SAKIT UMUM DAERAH PRAYA LOMBOK
}

\author{
Reni Agustina ${ }^{1}$ \\ I Gde Adnyana Sudibya ${ }^{2}$ \\ ${ }^{1,2}$ Fakultas Ekonomi dan Bisnis Universitas Udayana, Bali, Indonesia \\ email: reni_agustina84@yahoo.com
}

\begin{abstract}
ABSTRAK
Work Family Conflict merupakan salah satu konflik yang sering terjadi dikalangan perawat terutama perawat yang sudah menikah, dimana seorang perawat harus membagi waktu untuk urusan pekerjaan dan rumah tangga. Jika work family conflict tidak bisa dihindari, maka dapat menyababkan perawat stres dan kinerja mereka menurun. Sedangkan kinerja yang maksimal sangat dibutuhkan dalam pekerjaan sebagai seorang perawat, dimana harus menangani pasien sakit dengan resiko tinggi. Tujuan penelitian ini adalah untuk menganalisis pengaruh work family conflict terhadap stres kerja dan kinerja. Penelitian dilakukan di Rumah Sakit Umum Daerah Praya Lombok. Jumlah sampel yang diteliti adalah sebanyak 49 responden dengan metode purposive sampling dengan criteria wanita perawat yang sudah menikah. Data dikumpulkan dengan menyebar kuesioner dan menggunakan Path Analysis sebagai teknik analisis data. Uji Sobel juga digunakan untuk mengetahui apakah terjadi mediasi. Hasil penelitian ini menunjukkan bahwa work family conflict berepengaruh positif terhadap stres kerja, stres kerja berpegaruh negatif terhadap kinerja, work family conflict berpengaruh negatif terhadap kinerja, dan stres kerja memediasi pengaruh work family conflict terhadap kinerja. Implikasi praktis dari penelitian ini diharapkan dapat menjadi bahan pertimbangan bagi manajemen Rumah Sakit Umum Daerah Praya Lombok agar lebih memperhatikan kesejahteraan perawat yang mengalami work family conflict agar dapat mengurangi tingkat stres dan meningkatkan kembali kinerja perawat.
\end{abstract}

Kata kunci: Work Family Conflict, Stres kerja, dan Kinerja.

\begin{abstract}
Work Family Conflict is one of the most frequent conflicts among nurses in married nurses, where a nurse has to divide the time for business and household. If workplace family conflicts can not be avoided, then it can cause stress and performance. While the performance is much needed in the job as a nurse, which must be infected patients with high risk. The purpose of this study is analyze the effect of family conflict on job stress and performance. The research conducted at Praya Hospital. The number of samples study is 49 respondents with purposive sampling method with the criteria of female nurses who are married. Data with questionnaire distribution and using Path Analysis as data analysis techniques. The Sobel test is also used to determine whether there is mediation. The results of this study indicate that family conflict has a positive effect on job stress, work stress negatively affect the performance, and work family conflict negatively affect the performance,work stress is mediate the influence of conflict family on performance. Practical implications of this research are expected to be a consideration for the management of Praya Hospital to better pay attention to the welfare of nurses who experience family conflicts so as to reduce stress levels and improve the performance of nurses.
\end{abstract}

Keywords: Work Family Conflict, Work Stress, and Performance. 


\section{PENDAHULUAN}

Siregar dan Amelia, (2003) menyatakan "rumah sakit adalah suatu organisasi yang menyelenggarakan pelayanan kesehatan pasien, serta berbagai macam profesi kesehatan seperti fasilitas untuk diagnostik dan terapi dalam sistem untuk memelihara dan meningkatkan kesehatan masyarakat”. Rumah sakit juga didorong memberi pelayanan kesehatan yang bermutu dan terjangkau bagi setiap elemen masyarakat untuk meningkatkan pelayanan kesehatan yang optimal bagi masyarakat. Sehubugan dengan itu diperlukan perawat yang berkualitas dan professional.

Perawat professional adalah perawat yang mampu memberikan perawatan berkualitas untuk memenuhi kebutuhan kesehatan pasien. Perawat professional bukan hanya berperan melaksanakan perawatan saja tetapi juga mampu sebagai pendidik, komunikator dan manajer. Patrice, (2004) menyatakan "sebagai seorang wanita perawat dan juga ibu rumah tangga, tidaklah mudah dimana harus menjaga dan merawat pasien dan juga tanggung jawab sebagai ibu rumah tangga untuk mengurusi suami dan anak. Wanita perawat tidak dapat membagi atau menyeimbangkan waktu untuk urusan keluarga dan pekerjaan yang dapat menimbulkan konflik, yaitu konflik pekerjaan dan keluarga”

Yildirim dan Aycan, (2008) "perawat umumnya terdiri dari kaum wanita yang tidak bisa dilepaskan dari peran sebagai perempuan dituntut bertanggung jawab untuk mengurus dan membina keluarga namun disisi lain perempuan sebagai seorang perawat juga dituntut untuk bekerja sesuai kebijakan rumah sakit dengan menunjukkan kinerja dan kemampuan yang dimiliki”. Dengan demikian 
para wanita yang sudah bekerja dan berkeluarga, konsentrasinya mudah terganggu sehingga berdampak pada kegiatannya. Seperti seorang perawat yang harus menjaga pasiennya tetapi pada waktu yang bersamaan dia harus menjemput anaknya sekolah atau memasak untuk anak dan suaminya. Dalam hal ini dukungan suami sangat dibutuhkan dan menjadi partner dalam mengurus anak dan urusan rumah lainnya tetapi ada beberapa perawat yang suaminya tidak bisa dijadikan partner bahkan segala urusan rumah tangga harus dilakukan oleh sang istri.

Verma, (2013) "kondisi seperti itu sering memicu terjadinya konflik dalam pekerjaan, bila tidak ditangani secara serius akan menimbulkan dampak yang sangat berarti bagi organisasi dalam mencapai tujuannya, salah satunya adalah rendahnya kinerja perawat". Tidak hanya itu perawat yang mengalami keadaan serba salah antara keluarga dan pekerjaan bisa mengalami tekanan (stres). Looker dan Gregson, (2005: 44) "stres adalah sebuah keadaan yang dialami seseorang ketika ada ketidaksesuaian antara tuntutan-tuntutan yang diterima dan kemampuan untuk mengatasinya

Fenomena yang terjadi setiap hari bagi perawat RSUD Praya menghadapi tekanan pekerjaan yang berat, duka cita, bau, tangisan dan kematian. Setiap pagi perawat harus memonitor kondisi kesehatan pasien yang menjadi tanggung jawabnya. Perawat memeriksa kesiapan tempat tidur, obat, pemeriksaan rutin temperatur badan, dan tensi darah. Patricia et al. (2017) "perawat lebih banyak menghabiskan waktu dengan pasien dimana hal ini akan berdampak pada kualitas 
asuhan keperawatan. Dengan demikian perbaikan keamanan pasien bisa tercapai dengan cara meningkatkan kinerja perawat."

Kondisi lain yang menjadi sumber perawat stres adalah keluarga pasien yang berisik sehingga mengganggu pasien lainnya dan mengganggu konsentrasi perawat dalam mengerjakan tugasnya. Ada juga keluarga pasien yang bertanya berulang-ulang tentang keadaan keluarga yang dirawat sehingga waktu bekerja perawat sangat terganggu karena harus menjawab pertanyaan yang sama dari keluarga pasien, ditambah lagi keluarga maupun kerabat pasien yang datang lebih dari jam besuk tetapi ngotot untuk membesuk pasien sehingga perawat harus memberi penjelasan bahwa jam besuk sudah habis, padahal sudah jelas tertera pengumuman jadwal jam besuk untuk pasien. Kondisi lainnya yaitu perawat harus menjaga pasien yang sakitnya parah dengan alat kesehatan yang tidak begitu canggih dan lengkap. Abdullah et al. (2013) menyatakan "perawat yang bertugas shift malam diharuskan memeriksa semua pasien bahkan tidak jarang membawa pasien ke kamar mayat dimana perawat merasa ketakutan dan tidak tenang. Belum lagi mendapat keluhan dari anak dirumah yang kurang mendapat perhatian dari seorang ibu karena ibunya harus bekerja dan pulang malam dimana sang anak sudah tidur, belum lagi jika anak sakit dan harus manangani pasien disaat bersamaan, hal ini dapat menjadi sumber stres bagi perawat yang bekerja di rumah sakit sehingga dapat menyebabkan kinerja mereka menurun.”

Hasil wawancara dengan kepala keperawatan, wanita perawat mengalami penurunan kinerja. Penurunan kinerja disebabkan oleh adanya kesenjangan kinerja antara kenyataan dengan harapan terutama pada perawat yang memiliki peranan 
penting yakni berhubungan dengan pemberian layanan kesehatan dan ibu rumah tangga. Faktor lain yang juga menyebabkan kinerja perawat menurun yaitu meningkatnya jam mangkir yang dilakukan oleh perawat dan jam terlambat datang serta jam pulang cepat perawat mengalami peningkatan dalam tiga tahun terakhir pada tabel 1.1.

Perawat sering kali harus ijin istirahat lebih awal ke pasar untuk membeli sayuran. Perawat hanya ijin untuk membeli sayuran dan mengantar sayuran kerumah dengan alasan takut sayuran rusak jika tidak ditaruh dikulkas tetapi karena harus mengurus masalah keluarga seperti anak kelaparan saat pulang sekolah dan suami juga kelaparan saat pulang istirahat jadi tidak sedikit perawat yang mencuri waktu untuk memasak untuk keluarga mereka, perawat menggunakan waktu ijin melebihi dari yang diberikan atasan sehingga jam kerja perawat berkurang dari jam yang sudah ditentukan, berakibat kinerja mereka juga tidak optimal dimana jumlah pasien yang diperiksapun kurang dari seharusnya.

Kondisi anak sakit atau sang anak masih kecil butuh perhatian dan dirawat oleh ibunya sedangkan sang ibu harus merawat pasien ditempat kerja, dan mendengar suara anak nangis melalui telepon sedangkan sang ibu harus menangani pasien yang serius membuat konsentrasi perawat terganggu dan mengalami tekanan (stres) sehingga ia tidak mampu menyelesaikan pekerjaannya dengan baik. Hal ini juga didukung oleh penelitian Darcy dan Alma (2007), yang mengatakan bahwa "orang tua yang bekerja dan memiliki anak yang masih kecil tidak sepenuhnya dapat mengasuh anaknya dikarenakan pekerjaan yang harus diselesaikan." 
Tabel 1.1

Data Absensi Perawat RSUD Praya Lombok Periode 2014-2016

\begin{tabular}{ccccc}
\hline Tahun & Kehadiran & Mangkir & Terlambat & Pulang cepat \\
\hline 2014 & $96 \%$ & $8 \%$ & $6 \%$ & $4 \%$ \\
\hline 2015 & $94 \%$ & $12 \%$ & $10 \%$ & $8 \%$ \\
\hline 2016 & $90 \%$ & $16 \%$ & $14 \%$ & $10 \%$ \\
\hline Rata-rata & $93 \%$ & $12 \%$ & $10 \%$ & $7 \%$ \\
\hline
\end{tabular}

Sumber : Bagian personalia RSUD Praya Lombok

Berdasarkan data presensi perawat diatas, masih sering terjadi kemangkiran dalam melaksanakan pekerjaan, keterlambatan masuk kerja, dan banyak perawat yang pulang cepat sebelum waktunya sehingga banyak perawat yang tidak memanfaatkan waktu kerjanya untuk menyelesaikan pekerjaan. Akibatnya muncul beberapa keluhan dari pasien yang terjadi dalam pelayanan kesehatan RSUD Praya Lombok. Keluhan muncul mulai dari kedatangan perawat yang menyebabkan keterlambatan dalam memeriksa kondisi pasien dan sistem administrasi yang tidak disiplin. Apabila kondisi tersebut dibiarkan, maka akan mempengaruhi kinerja RSUD Praya Lombok secara keseluruhan. Oleh karena itu, diperlukan upaya perbaikan dalam menunjang pelaksanaan pekerjaan sehingga kinerja perawat bisa lebih baik.

Pihak rumah sakit perlu memperbaiki kualitas dan kuantitas perawat dimana prosedur keperawatan yang dilakukan sudah sesuai dengan ketentuan yang ada dan mencapai target. Perlu siaga dalam mengawasi pasien, mencari bantuan dan bekerja sama dengan perawat lainnya sehingga pekerjaan dapat diselesaikan tepat waktu. Perawat yang tidak dapat melaksanakan pekerjaannya 
sesuai dengan jadwal dikarenakan adanya urusan keluarga dapat bertukar shift dengan perawat lain sehingga tugas-tugas tidak terhambat

Hasil wawancara secara personal pada 10 orang wanita perawat yang telah menikah dimana beberapa diantara mereka mengatakan bahwa konsentrasi mereka sering terganggu akibat kelelahan dan pikiran mereka terbagi antara urusan keluarga dan pekerjaan. Mereka mengatakan sering datang terlambat dikarenakan harus mengurus anak dan suami terdahulu. Mereka mengaku sering mendapat teguran dari atasan karena pekerjaan terganggu oleh urusan lain sehingga pekerjaan tidak dapat diselesaikan tepat waktu.

Beberapa peneliti terdahulu mengatakan Work Family Conflict dapat berpengaruh pada stres kerja. Hal ini sesuai dengan penelitian yang dilakukan oleh Indriyani (2009) yang mengatakan "semakin tinggi konflik pekerjaan keluarga, maka semakin tinggi stres kerja. Hubungan variabel konflik keluargapekerjaan berpengaruh positif terhadap terjadinya stres kerja." Sedangkan Selamet (2009) mengatakan "konflik keluarga-pekerjaan mempunyai pengaruh positif yang tidak signifikan terhadap variabel job stress atau stres kerja."

Mai dan Vu (2016) menyatakan bahwa "stres kerja berpengaruh terhadap kinerja karyawan, Semakin tinggi tingkat stres kerja pegawai dapat menurunkan kinerja pegawai, dan sebaliknya semakin rendah tingkat stres kerja pegawai, maka kinerja pegawai akan semakin meningkat”. Sedangkan Price (2003) dalam Indriyani (2009) mengatakan bahwa "stres ditempat kerja juga berhubungan positif dengan kinerja karyawan. Stres dapat menciptakan keunggulan kompetitif bagi perusahaan dengan manajemen yang baik. Stres juga memberikan dampak 
positif yang lain seperti dengan adanya batasan waktu perusahaan dapat menjadi lebih efisien dan efektif."

Konflik pekerjaan-keluarga berpengaruh pada kinerja karyawan hal ini didukung oleh penelitian yang dilakukan Retnaningrum dan Mochammad (2016), menunjukkan "work intereference with family berpengaruh negatif signifikan terhadap kepuasan kerja perawat dan kinerja perawat, family intereference with work berpengaruh negatif signifikan terhadap kepuasan kerja perawat dan kinerja perawat". Berbeda dengan penelitian Retnaningrum, Amelia (2010), hasil penelitiannya mengatakan bahwa "tidak ada hubungan antara work-family conflict dan kinerja. Hal ini terjadi karena karyawan tidak merasa bahwa tekanan yang terjadi di kantor mempengaruhi dirinya dalam melakukan aktivitas di rumah sehingga secara tidak langsung tidak mempengaruhi kinerjanya saat di kantor”.

Frone et al. (1992) mendefinisikan "work family conflict sebagai konflik peran yang terjadi pada karyawan, dimana di satu sisi ia harus melakukan pekerjaan di kantor dan di sisi lain harus memperhatikan keluarga secara utuh, sehingga sulit membedakan antara pekerjaan mengganggu keluarga dan keluarga mengganggu pekerjaan”. Pekerjaan mengganggu keluarga, artinya sebagian besar waktu dan perhatian dicurahkan untuk melakukan pekerjaan sehingga kurang mempunyai waktu untuk keluarga. Sebaliknya keluarga mengganggu pekerjaan berarti mengurus keluarga ditengah urusan pekerjaan. Work Family Conflict ini terjadi ketika kehidupan rumah seseorang berbenturan dengan tanggung jawabnya ditempat kerja, seperti masuk kerja tepat waktu, menyelesaikan tugas harian, atau kerja lembur. Demikian juga tuntutan kehidupan rumah yang menghalangi 
seseorang untuk meluangkan waktu untuk pekerjaannya atau kegiatan yang berkenaan dengan kariernya.

Stres kerja menurut Handoko (2011:200) adalah "kondisi ketegangan yang mempengaruhi emosi, proses berpikir dan kondisi seseorang. Stres yang terlalu besar dapat mengancam kemampuan seseorang untuk menghadapi lingkungan. Sebagai hasilnya, pada diri para karyawan berkembang berbagai macam gejala stres yang dapat mengganggu pelaksanaan kerja mereka. Gejala-gejala ini menyangkut baik kesehatan fisik maupun kesehatan mental. Orang-orang yang mengalami stres bisa menjadi nerveous dan merasakan kekhawatiran kronis. Mereka sering menjadi mudah marah dan agresif, tidak dapat relaks, atau menunjukkan sikap yang tidak kooperatif. Mereka biasanya sering melarikan diri dengan minum alkohol atau merokok secara berlebihan. Di samping itu, mereka bahkan bisa terkena berbagai penyakit fisik, seperti masalah pencernaan atau tekanan darah tinggi, serta sulit tidur. Kondisi-kondisi tersebut meskipun dapat juga terjadi karena penyebab-penyebab lain, tetapi pada umumnya hal itu merupakan gejala-gejala stres".

Kinerja merupakan masalah yang sentral dalam kehidupan sebuah organisasi karena sebuah organisasi atau perusahaan akan mampu mencapai tujuan atau tidak, sangat penting tergantung pada sebaik apa kinerja yang ditunjukkan oleh para karyawannya. Karyawanlah yang menentukan apakah sumber daya organisasi yang lain, seperti gedung-gedung, mesin, peralatan kerja, uang, bahan baku, dan lainlain dapat memberikan kontribusi optimal atau tidak terhadap upaya pencapaian tujuan organisasi. Suparyadi, (2015: 300) "strategi apa pun yang 
dipilih oleh organisai dalam menjalankan bisnisnya, terutama apabila strategi yag dipilih adalah dferensiasi atau bisnis bidang jasa, maka unsur karyawan memiliki posisi yang sentral, mereka menjadi penentu keberhasilan bisnis yang dijalankan”.

Berdasarkan latar belakang peneliti di atas, sehingga dapat digambarkan konsep penelitian ini pada Gambar 3.1:

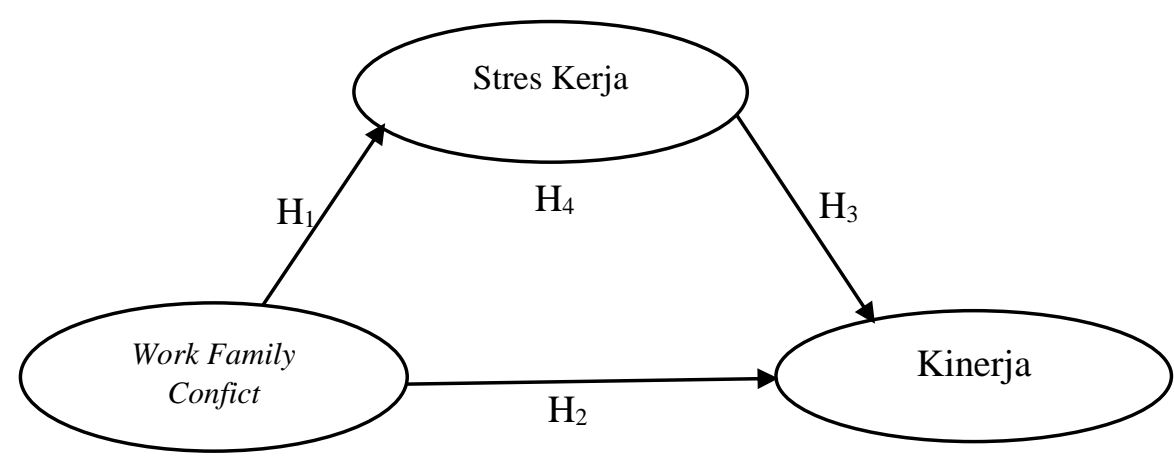

Gambar 3.1 Kerangka Konseptual

Hubungan pengaruh antara work family conflict terhadap stres kerja sesuai dengan penelitian Karabaya et al. (2013) menunjukkan bahwa "konflik keluargapekerjaan mempengaruhi beban kerja, lingkungan kerja yang buruk dan peran yang buruk". Kazmi et al. (2017) mengatakan bahwa "masalah kerja dan keluarga menjadi semakin penting bagi individu maupun organisasi, karena dampak negatifnya. Hasil penelitiannya menunjukkan bahwa, stres kerja secara signifikan terkait dengan konflik keluarga kerja rekomendasi bagian dari penelitian menunjukkan bahwa, Bank harus perlu mendukung dan tetap rileks pada stafnya, tanpa tekanan pada pekerjaan”. Novianti (2015), hasil penelitiannya menunjukkan bahwa "jika ada WFC dialami oleh karyawan dengan PsyCap rendah dapat meningkatkan stres kerja. Hasil penelitian ini dapat digunakan untuk membantu 
karyawan mengembangkan potensi mereka dalam mempersiapkan untuk mengatasi masalah itu muncul karena adanya tuntutan di tempat kerja dan tanggung jawab keluarga”. Lu Yong et al. (2017), “jam kerja seorang pegawai yang berlebih akan mengalami tekanan dimana ia harus mrnghabiskan lebih banyak waktu dikantor dari pada bersama keluarga, serta usia mereka yang sudah lanjut akan cepat mengalami kelelahan". Dari uraian tersebut, maka hipotesis penelitian ini adalah:

$\mathrm{H}_{1}$ : Work Family Conflict berpengaruh positif dan signifikan terhadap stres kerja wanita perawat rumah sakit umum daerah praya

Hubungan pengaruh stres kerja terhadap kinerja karyawan sesuai dengan penelitian Lalu dan Lapian (2016), "karyawan adalah salah satu bagian penting dari perusahaan. Beberapa bagian yang akan menjalankan strategi dari perusahaan dengan maksud mencapai tujuan adalah karyawan. Kinerja dari perusahaan dapat dilihat dari pencapaian positif karyawan. Konflik dalam kehidupan yang sering terbawa ke tempat kerja sehingga karyawan mengalami tekanan (stres) yang mana berpotensial mempengaruhi kinerja dari karyawan pada pekerjaan”. Bashir dan Muhammad (2010), hasil penelitiannya "signifikan dengan korelasi negatif antara stres kerja dan kinerja kerja dan menunjukkan bahwa stres kerja secara signifikan mengurangi kinerja seseorang. Hasilnya menunjukkan bahwa organisasi harus memfasilitasi budaya pendukung dalam suasana kerja organisasi”. Berdasarkan uraian diatas, maka hipotesis penelitian ini adalah:

$\mathrm{H}_{2}$ : Stres kerja berpengaruh negatif dan signifikan terhadap kinerja wanita perawat rumah sakit umum daerah praya 
Hubungan pengaruh work family conflict terhadap kinerja karyawan sesuai dengan penelitian Jackson dan Ariyanto (2017), "Nilai Work-to-Family Conflict (-0.236 X1) adalah negatif, artinya Work-to-Family Conflict memberikan pengaruh yang negatif terhadap kinerja karyawan. Nilai Family-to-Work Conflict (-0.404 X2) adalah negatif, artinya Family-to-Work Conflict memberikan pengaruh yang negatif terhadap kinerja karyawan. Semakin tinggi Work-to-Family Conflict dan Family-to-Work Conflict pada karyawan, semakin rendah kinerjanya". Asfahyadin et al. (2017), "konflik Keluarga-Pekerjaan memiliki signifikan negatif berpengaruh terhadap kinerja karyawan. Dengan kata lain, semakin tinggi konflik yang dihadapi karyawannya akan, semakin rendah kinerjanya. Ini berarti dengan meminimalkan dan mengantisipasi Konflik Keluarga-Keluarga dengan baik, akan terjadi meningkatkan kinerja karyawan”. Dari uraian di atas tersebut, maka hipotesis penelitian ini adalah:

$\mathrm{H}_{3}$ : Work Family Conflict berpegaruh negatif dan signifikan terhadap kinerja wanita perawat rumah sakit umum praya

Hubungan pengaruh pengaruh work family conflict terhadap kinerja perawat yang dimediasi oleh stres kerja Irviana (2016), menunjukkan bahwa "beban di tempat kerja menyebabkan responden mengalami emotional exhaustion. Hal ini salah satunya disebabkan kurangnya jumlah tenaga perawat terkadang mengakibatkan mereka harus bekerja lembur serta tekanan pekerjaan sebagai tenaga non paramedis. Bahkan pada beberapa responden, hal ini bisa menyebabkan kurangnya kebersamaan mereka dengan anggota keluarga”. Iqbal (2016), "penelitiannya dilakukan berdasarkan kondisi kinerja organisasi di RSUD 
Menggala yang menunjukkan ketidak tercapaian target kinerja organisasi yang telah ditetapkan oleh departemen kesehatan, hal ini sejalan dengan indikator kinerja individu pegawai yang ditunjukkan dari data tingkat kehadiran pegawai yang rendah”. Hal ini didukung dengan penelusuran awal penelitian yang memperlihatkan bahwa komposisi pegawai didominasi oleh pegawai wanita yang sudah berkeluarga, yaitu sebanyak $63 \%$. Kondisi ini yang dikaitkan dengan teori konflik peran ganda dan stress kerja. Harsono et al. (2013), “jenis penelitiannya adalah rancangan dengan analisis cross sectional, untuk mengetahui bagaimana konflik peran ganda terhadap kinerja dengan stres kerja sebagai variabel mediasi. Berdasarkan hasil penelitian juga menunjukkan bahwa stres kerja mampu menengahi konflik antara peran ganda dengan kinerja”. Penelitian Natalia dan Suharmono (2015) ; Wibowo dan Edi (2015) ; Nurqamar et al. (2014) juga mengatakan "work family conflict berpengaruh tidak langsung terhadap kinerja melalui stres kerja". Dari uraian di atas tersebut, maka hipotesis penelitian ini adalah:

$\mathrm{H}_{4}$ : Stres kerja memediasi pengaruh work family conflict dengan kinerja wanita perawat

\section{METODE PENELITIAN}

Melihat permasalahan yang diteliti, penelitian ini digolongkan dalam pendekatan kausalitas (sebab akibat) adalah pendekatan yang mampu menunjukkan hubungan diantara dua variabel atau lebih (Sugiyono, 2013:5). Penelitian ini dilakukan untuk mengetahui pengaruh work family conflict terhadap 
stres dan kinerja wanita perawat di Rumah Sakit Umum Daerah Praya Lombok. Responden akan diberikan beberapa pernyataan dalam bentuk kuesioner dengan alternatif jawaban terdiri dari rentang nilai 1-5. Pada penelitian ini terdapat tiga jenis variabel yakni, variabel independen (work family conflict), variabel dependen (kinerja perawat), dan variabel mediasi (stres kerja). Penelitian ini akan dilakukan di Rumah Sakit Umum Daerah Praya yang terletak di Jln. H. Lalu Hasyim, Tiwugalih, Praya - Lombok.

Penelitian ini menggunakan Purposive Sampling dimana pengambilan sampel dilakukan untuk mewakili sampel yang telah ditentukan berdasarkan pertimbangan atau kriteria yang dibutuhkan oleh peneliti (Rahyuda, 2016:154). Artinya setiap subjek yang diambil dari populasi dipilih dengan sengaja berdasarkan tujuan dan pertimbangan tertentu. Tujuan dan pertimbangan subjek atau sampel dalam penelitian ini adalah (1) Sampel tersebut adalah wanita perawat, (2) Berstatus menikah, Dan (3) bekerja di rumah sakit umum daerah praya lombok. Jumlah sampel yang digunakan sebanyak 49 wanita perawat rumah sakit umum daerah praya lombok.

Pada penelitian ini digunakan teknik analisis jalur atau disebut juga sebagai Path Analysis. "Analisis jalur (path analysis) digunakan untuk menguji seberapa besar kontribusi yang dinyatakan oleh koefisien jalur di setiap diagram jalur dari hubungan kausal atau sebab akibat yang tercipta dari variabel independen terhadap variabel dependen" (Riduwan, 2012). Dasar perhitungan koefisien jalur membutuhkan perhitungan dari analisis korelasi dan regresi yang kemudian dituangkan dalam software berupa SPSS for windows. Dimana terdapat 
dua anak panah dalam pembentukan diagram alur yaitu: anak panah satu arah yang mencerminkan suatu pengaruh variabel independen terhadap variabel dependen dan anak panah dua arah yang mencerminkan suatu hubungan yang terjadi antara variabel dependen.

\section{HASIL DAN PEMBAHASAN}

Uji sobel digunakan untuk menguji kekuatan pengaruh tidak langsung variabel independen $(\mathrm{X})$ ke variabel dependen $(\mathrm{Y})$ melalui variabel mediator $(\mathrm{M})$ (Preacher dan Hayes, 2004). Pengaruh tidak langsung X ke Y melalui M dihitung dengan cara mengalikan jalur $\mathrm{X} \rightarrow \mathrm{M}$ (1) dengan jalur $\mathrm{M} \rightarrow \mathrm{Y}(2)$ atau ab. Jadi koefisien $\mathrm{ab}=\left(\mathrm{c}-\mathrm{c}^{\prime}\right)$, dimana $\mathrm{c}$ adalah pengaruh $\mathrm{X}$ terhadap $\mathrm{Y}$ dengan tidak mengontrol $\mathrm{M}$, sedangkan c' adalah koefisien pengaruh $\mathrm{X}$ terhadap $\mathrm{Y}$ sesudah mengontrol M. Standard error koefisien a dan b ditulis dengan Sa dan Sb, besarnya standard error pengaruh tidak langsung (indirecteffect) Sab dihitung menggunakan rumus dibawah ini :

1. $S a b=\sqrt{\mathrm{b}^{2} \mathrm{Sa}^{2}+\mathrm{a}^{2} \mathrm{Sb}^{2}+\mathrm{Sa}^{2} \mathrm{Sb}^{2}}$

$$
\begin{aligned}
& =\sqrt{(-0,814)^{2}(0,121)^{2}+(0,562)^{2}(0,052)^{2}+(0,121)^{2}(0,052)^{2}} \\
& =0,1029
\end{aligned}
$$

2. Untuk menguji signifikansi pengaruh tidak langsung, maka kita perlu menghitung nilai t dari koefisien ab dengan rumus sebagai berikut :

$$
\begin{aligned}
& t=\frac{a b}{S a b}=\frac{-0,4575}{0,102931} \\
& =-4,444
\end{aligned}
$$


3. Nilai $\mathrm{t}$ hitung ini dibandingkan dengan nilai $\mathrm{t}$ tabel yaitu $\leq-1,96$. Berdasarkan hasil analisis sobel diperoleh nilai t hitung $(-4,444)$ lebih kecil atau kurang dari nilai t tabel $(-1,96)$.

4. Kesimpulan

Hasil perhitungan uji Sobel menunjukkan bahwa nilai $\mathrm{t}=-4,444<-1,96$ yang berarti variabel mediasi yakni stress kerja dinilai memediasi hubungan antara work family conflict terhadap kinerja wanita perawat Rumah Sakit Umum Daerah Praya.

Pengaruh Work Family Conflict terhadap stres kerja, Work Family Conflict berpengaruh positif terhadap stres kerja, maka $\mathrm{H}_{1}$ diterima. Berdasarkan hasil analisis pengaruh Work Family Conflict terhadap stres kerja diperoleh nilai Signifikansi sebesar 0,000 dengan nilai koefisien beta 0,562. Nilai Signifikansi $0,000<0,05$. Ini berarti semakin tinggi work family conflict yang dialami perawat maka semakin tinggi pula stres yang dialami perawat. Work family conflict diukur berdasarkan dimensi time based conflict, strain based conflict, dan behavior based conflict.

Hasil analisis menunjukkan bahwa wanita perawat yang sudah menikah yang mengalami peran ganda dimana harus menjalani peran sebagai perawat sekaligus ibu rumah tangga sulit untuk membagi waktu antara pekerjaan dan urusan rumah tangga. Banyaknya waktu yang dibutuhkan dan tekanan dalam menjalani dua peran untuk menangani urusan pekerjaan dan urusan rumah tangga dapat menjadi sumber potensial terjadinya stres kerja dimana terkadang urusan rumah tangga mengganggu pekerjaan begitu juga sebaliknya. 
Hasil penelitian ini mengkonfirmasi beberapa hasil penelitian terdahulu seperti penelitian yang dilakukan oleh Divara (2016), dalam penelitiannya yang dilakukan pada Dinas Kebudayaan Provinsi Bali mengemukakan "adanya pengaruh positif antara work family conflict dan stres kerja, dimana konflik yang dialami oleh seorang karyawan dapat meningkatkan stres, sehingga semakin tinggi work family conflict yang dialami karyawan maka semakin tinggi juga stres kerjanya". Rajak (2013) mengatakan "semakin tinggi work family conflict yang dialami pegawai maka semakin tinggi juga stres kerja yang dialami. Terdapat pengaruh positif work family conflict sebagai akibat dari interfensi pekeraan terhadap stres kerja pegawai negri sipil di secretariat jendral kementrian Pendidikan dan kebudayaan". Nurnazirah et al. (2015) mengatakan “work family conflict dan stres kerja menunjukkan adanya hubungan yang signifikan". Penelitian ini didukung juga oleh Hammer et al. (2004), Bazana and Dodd (2013), Indriyani (2009) dalam penelitiannya mengatakan "semakin tinggi work family conflict, maka semakin tinggi pula stres kerja yang dialami karyawan”.

Pengaruh stres kerja terhadap kinerja, stres kerja berpengaruh negatif terhadap kinerja, maka $\mathrm{H}_{2}$ diterima.Berdasarkan hasil analisis pengaruh stres kerja terhadap kinerja diperoleh nilai Signifikansi sebesar 0,000 dengan nilai koefisien beta $-0,814$. Nilai Signifikansi $0,000<0,05$. Ini berarti semakin tinggi stres yang dialami perawat maka semakin rendah pula kinerjanya. Stres kerja diukur dengan dimensi workload, pressure, dan conflict.

Hasil analisis menunjukkan bahwa perawat yang mengalami stres yang diakibatkan oleh beban kerja yang berlebih maupun tekanan dari luar dan dalam 
organisasi dapat menjadi penghambat dalam memperoleh kinerja yang baik. Seseorang yang mengalami stres akan sulit bagi mereka untuk berinteraksi dan menyelesaikan tugas secara maksimal. Kondisi stres juga dapat menimbulkan kegelisahan, menurunnya konsentrasi, depresi, dll.

Hasil penelitian ini mengkonfimasi beberapa hasil penelitian terdahulu seperti penelitian yang dilakukan oleh Riandy (2016), mengatakan "bahwa karyawan sering merasa tertekan baik secra mental maupun fisik akibat tugas yang berat. Karyawan juga merasa jenuh karena jam kerja yang berlebih dan waktu istirahat yang kurang sehingga pekerjaan mereka tidak optimal". Astianto dan Heru (2014), hasil penelitiannya mengatakan "semakin tinggi stres yang dialami maka akan mengurangi kinerja. Karyawan mengalami stres dan tantangan-tantangan kerja semakin banyak sehingga kinerja juga menurun”. Dewi et al. (2014), "Stres kerja berpengaruh secara negatif dan signifikan terhadap kinerja karyawan". Zeb et al. (2015) mengatakan bahwa "stres kerja mempunyai pengaruh yang negatif dan signifikan terhadap kinerja karyawan di Perbankan Sektor di Khyber Pakhtunkhwa Pakistan dimana stres kerja tinggi maka kinerja rendah pula, demikian sebaliknya". Dewi (2016) mengatakan bahwa "adanya pengaruh negatif antara variabel stres kerja dan kinerja karyawan". Penelitian ini didukung juga oleh Siu (2003); Choi et al. (2014) yang mengatakan bahwa "saat stres kerja sangat tinggi maka karyawan akan menghasilkan kinerja yang rendah".

Pengaruh Work Family Conflict terhadap Kinerja Perawat, Work family conflict berpengaruh negatif terhadap kinerja, maka $\mathrm{H}_{3}$ diterima. Berdasarkan hasil analisis pengaruh work family conflict terhadap kinerja diperoleh nilai 
signifikansi sebesar 0,000 dengan nilai koefisien beta $-0,222$. Nilai Sig. t 0,000< 0,05. Ini berarti semakin tinggi work family conflict yang dialami perawat maka semakin rendah pula kinerjanya. Kinerja diukur dengan dimensi kualitas, kuantitas, ketepatan waktu, efektivitas, dan kemampuan bekerjasama.

Hasil analisis menunjukkan bahwa work family conflict yang dialami perawat dapat menurunkan kinerjanya, dimana seorang perawat gagal memenuhi peran ganda karena sering kali pekerjaan mengganggu keluarga atau sebaliknya keluarga mengganggu pekerjaan sehingga tidak mudah bagi perawat untuk membagi waktu mereka diantara dua peran tersebut. Sering kali perawat istirahat melebihi waktu normal istirahat karena harus mengurus keluarga, sehingga waktu bekerja berkurang dari seharusnya. Hal inilah yang menimbulkan kinerja mereka tidak maksimal.

Hasil penelitian ini mengkonfirmasi beberapa hasil penelitian terdahulu seperti penelitian yang dilakukan oleh Tewal dan Florensial (2014), mengatakan bahwa "semakin rendah tingkat konflik peran akan menyebabkan semakin tingginya kinerja wanita karir, begitu sebaliknya semakin tinggi tingkat konflik peran, maka semakin rendahnya kinerja wanita karir”. Anwar dan Shazad (2011), dalam penelitiannya mengatakan bahwa "work family conflict berpengaruh negatif dengan stres maupun kinerja". Chintya et al. (2006), mengatakan bahwa "wanita yang sudah menikah mengalami work family conflict yang jauh lebih tinggi dibandingkan wanita yang belum menikah dan wanita yang mengalami work family conflict yang tinggi lebih banyak mengalami penurunan kinerja". Penelitian 
ini didukung juga oleh Charlson et al. (2000); Ahmad (2008); Karatepe dan Kilic (2007) yang mengatakan hal serupa dengan pebeliti sebelumnnya.

Pengaruh work family conflict terhadap kinerja yang dimediasi oleh stres kerja, Work family conflict berpengaruh negatif terhadap kinerja melalui stres kerja, maka $\mathrm{H}_{4}$ diterima. Hasil perhitungan uji Sobel menunjukkan bahwa nilai $\mathrm{t}=$ $-4,444<-1,96$ yang berarti variabel mediasi yakni stres kerja dinilai memediasi hubungan antara work family conflict terhadap kinerja wanita perawat Rumah Sakit Umum Daerah Praya. Ini berarti work family conflict yang dialami perawat secara tidak langsung dapat menurunkan kinerja.

Hasil analisis menunjukkan bahwa work family conflict yang dialami perawat, dimana perawat kesulitan membagi waktu antara pekerjaan dan urusan rumah tangga sehingga konflik dalam keluarga sering dibawa ketempat kerja, sehingga dapat menyebabkan stres karena beban kerja yang dialami yang dapat menurunkan konsentrasi maka berpotensi mempengaruhi kinerja seseorang dalam bekerja tidak maksimal. Work family conflict berpengaruh tidak langsung terhadap kinerja, dimana semakin tinggi work family conflict yang dialami perawat, maka semakin tinggi juga stres yang dirasakan akibat beban kerja sebagai perawat dan ibu rumah tangga sehingga semakin rendah pula kinerjanya. Berdasarkan nilai perhitungan uji sobel yang menguji stres kerja memediasi antara variabel work family conflict terhadap kinerja, maka dapat dimaknai dalam penelitian ini tingkat stres kerja perawat dapat mempengaruhi hubungan antara work family conflict terhadap kinerja. 
Hasil penelitian ini mengkonfirmasi beberapa penelitian sebelumnya Irviana (2016) mengatakan "beban ditempat kerja menyebabkan responden mengalami emotional exhaustion yang disebabkan kurangnya jumlah tenaga kerja sehingga harus terpaksa lembur". Iqbal (2016), "kondisi kinerja organisasi di RSUD Menggala yang menunjukkan ketidak tercapaian target diakibatkan karena tingkat kehadiran pegawai yang rendah dan didominasi oleh pegawai wanita yang sudah berkeluarga". Harsono et al. (2013) yang mengatakan "stres kerja memediasi pengaruh work family conflict terhadap kinerja karyawan". Natalia dan Suharnomo (2015), Penelitiannya menemukan bahwa "Work family conflict berpengaruh negatif dan signifikan secara tidak langsung terhadap kinerja karyawan melalui stres kerja". Hal ini berati stres kerja yang mengintervensi work family conflict yang dialami oleh karyawan lebih bersifat destruksif sehingga menyebabkan kinerja menurun. Wibowo dan Edi (2015), "Pengaruh intervening diuji dengan sobel test dan dihasilkan nilai t hitung sebesar 1,321 pada pengaruh konflik peran terhadap kinerja karyawan melalui stress kerja. Pengaruh tidak langsung work family conflict terhadap kinerja karyawan dengan stress kerja sebagai variabel intervening menunjukan bahwa dengan adanya konflik dalam keluarga dapat mengakibatkan kinerja karyawan menjadi turun”.

\section{SIMPULAN DAN SARAN}

Berdasarkan hasil penelitian dan pembahasan pada bab sebelumnya, maka didapat kesimpulan yaitu : 
1. Work family conflict berpengaruh positif dan signifikan terhadap stres kerja. Hal ini berarti bahwa semakin tinggi work family conflict perawat, maka semakin tinggi stres yang dialami.

2. Stres kerja berpengaruh negatif dan signifikan terhadap kinerja. Hal ini berarti bahwa semakin tinggi stres kerja yang dialami perawat, maka semakin rendah kinerja yang dihasilkan.

3. Work family conflict berpengaruh negatif dan signifikan terhadap kinerja. Hal ini berarti bahwa semakin tinggi work family conflict yang dialami perawat, maka semakin rendah kinerja yang dihasilkan.

4. Stres kerja memediasi antara pengaruh work family conflict terhadap kinerja. Hal ini berarti bahwa munculnya work family conflict yang dialami oleh perawat secara tidak langsung dapat menurunkan kinerja melalui stres kerja.

Berdasarkan hasil penelitian, berikut ini beberapa saran untuk manajemen RSUD Praya dalam menentukan kebijakan dimasa yang akan datang terutama tentang Work family conflict, stres kerja dan kinerja perawat.

1. Dukungan dari organisasi juga perlu ditingkatkan, dukungan organisasi memiliki pengaruh yang besar terhadap perawat sebagai motivasi mereka untuk tetap loyal kepada perusahaan. Dukungan tersebut bisa datang dari atasan dimana atasan memberikan keringanan waktu untuk perawat dalam mengerjakan tugas, misalkan perawat mengambil waktu lebih dalam istirahat namun perawat harus mengganti waktu tersebut pada saat jam pulang, waktu pulang akan terlambat dikarenakan perawat harus menyelesaikan tugas yang ditinggalkan pada saat jam istirahat. Apabila hal tersebut dapat dilakukan 
maka perawat akan merasa bahwa mereka merupakan bagian penting dalam organisasi sehingga akan tercapai saling mendukung antara perawat dan oganisasi dalam mencapai tujuan organisasi.

2. Persiapkan alat-alat penunjang keperawatan untuk perawat sehingga perawat merasa aman dalam mengerjakan tugasnya seperti menyediakan masker, sarung tangan, hand sanitizer, dll, sehingga perawat tidak tertular penyakit dari pasien dan tetap steril.

3. Kinerja wanita perawat di RSUD Praya Lombok perlu ditingkatkan lagi mengingat adanya beberapa indikator yang nilainya masih rendah. Pihak manajemen diharapkan dapat memberikan sosialisasi keperawatan secara bertahap kepada perawat sehingga perawat lebih percaya diri dalam mengerjakan tugasnya. Perawat tidak akan merasa ragu dalam melakukan suatu tindakan dalam situasi darurat dan dapat bekerja sama dengan perawat lainnya.

\section{IMPLIKASI PENELITIAN}

Implikasi Teoritis, hasil penelitian menyatakan bahwa Work family conflict berpengaruh positif terhadap stres kerja. Work family conflict berpengaruh negatif terhadap kinerja. Stres kerja juga berpengaruh negatif terhadap kinerja.

Thomas dan Ganster (1995), “beberapa bukti menjelaskan bahwa tekanan yang terjadi antara peran keluarga dan pekerjaan dapat menurunkan fisik dan psikologis seseorang". Tekanan yang terjadi akibat berperan sebagai seorang perawat sekaligus ibu rumah tangga dapat menyebabkan terjadinya stres akibat beban pekerjaan yang menjadi tanggug jawab. Work family conflict adalah salah 
satu bentuk konflik yang dapat mengganggu pekerjaan dimana perawat harus mengurus pasien dan keluarga secara bersamaan. Thomas dan Ganster juga mengatakan bahwa pria dan wanita yang sudah menikah dan bekerja akan mengalami stres dan hasil kerja yang diperoleh diidentifikasikan terjadinya ketidakpuasan kerja, kemangkiran, dan depresi yang dapat menyebabkan konsentrasi menurun sehingga kinerja tidak maksimal. Hasil penelitian ini diharapkan dapat menjadi bukti empiris yang terkait dengan work family conflict, stres kerja, dan kinerja dalam bidang jasa rumah sakit.

Implikasi Praktis, berdasarkan hasil survei, work family conflict berpengaruh pada stres dan kinerja perawat. Dalam upaya menekankan kualitas kerja maka diperlukan perhatian khusus bagi perawat yang ada di RSUD Praya terutama perawat yang sudah menikah dimana perawat yang sudah berkeluarga memiliki tanggung jawab double dan beban kerja lebih banyak.

Hasil survei menunjukkan bahwa perawat yang sudah berkeluarga mengalami work family conflict dimana perawat menjalani peran sebagai perawat dan ibu rumah tangga sekaligus sehingga otomatis beban kerja juga lebih banyak, disatu sisi harus merawat pasien dan juga mengurus suami dan anak. Perawat susah membagi waktu antara pekerjaan dan urusan rumah tangga. Dalam hal ini, maka perlu diperhatikan oleh pimpinan Rumah Sakit Umum Daerah Praya untuk memberikan waktu luang yang lebih dan kebijakan-kebijakan lain yang memang diperlukan oleh perawat terutama perawat yang sudah berkeluarga sehingga dapat mengurangi work family conflict yang dialami wanita perawat di Rumah Sakit Umum Daerah Praya. 
Temuan survei juga menunjukkan bahwa perawat yang sudah berkeluarga mengalami stres kerja dimana perawat yang tidak dapat membagi waktu antara keluarga dan pekerjaan mengalami beban kerja berlebih sehingga mengalami tekanan, tekanan inilah yang dikatakan stres. Beberapa karyawan yang memiliki anak masih kecil harus terpaksa membawa anak mereka ke rumah sakit dan harus merawat pasien juga, otomatis pekerjaan juga akan terganggu oleh kehadiran anak ditempat kerja, belum lagi beberapa keluhan dari keluarga pasien yang dapat menimbulkan stres. Dalam hal ini, perlu diperhatikan oleh pimpinan Rumah Sakit Umum Daerah Praya untuk mengadakan liburan bersama secara bertahap dalam rangka mengurangi tingkat stres yang dialami perawat dan membangun kerjasama yang baik.

Hasil survei juga mengatakan bahwa kinerja perawat yang sudah menikah menurun dikarenakan mengalami work family conflict dan stres kerja dimana perawat harus merawat pasien dan urusan keluarga. Beban kerja yang berlebih dapat mengurangi konsentrasi sehingga kinerja perawat tidak maksimal. Dalam hal ini, perlu diperhatikan oleh pimpinan Rumah Sakit Umum Daerah Praya untuk mengurangi tingkat stres dan work family conflict yang dialami perawat untuk meningkatkan kembali kinerja perawat.

\section{REFERENSI}

Abdullah, M. A., Faridahwati, M. S., Chandrakantan, S.,and Rabiul, I. 2013. Effect Of Job Stress and Organizational Support on the Relationship between ob Demand Resources and Nurses, Job Performance in Saudi Arabia Public Hopital. Australian Journal of Basic and Applied Science, (7), (1), 7-19. 
Abrokwah, B. K., Theophilus, A. R., Cecilia, T. D., and Catherine S. A. 2015. Examining Work and Family Conflict among Female Bankers in Accra Metropolis, Ghana. Journal of Education and Practice , (6), (1), 61-68.

AbuAlRub, R. F. 2004. Job stres, job performance, and social support amonghospital nurses. Journal of Nursing Scholarship, (36), (1), 73-78.

Ahmad, A. 2008. Direct and Indirect Effect of ork Family Conflict on Job Performance. The Journal of International Management Studies, (3), (2), 176-180.

Ali, W. U., Ahmed, R. R., Ahmad N.,and Khoso I. 2014. Impact of Stres on Job Performance: An Empirical study of the Employees of Private Sector Universities of Karachi, Pakistan. Journal of Management Sciences(3), (7), 14-17.

Andreassi, J. K., and Thompson, C. A. 2007. Dispositional and situational sources of control: relative impact on work-family conflict and positive spillover. Journal of ManagerialPsychology, (22), (8), 722-740.

Anwar, M. and Shazad, Khurram. 2011. Impact of Work Family Conflict on Perceived employee performance: Evidence from Pakistan. European Journal of Economics, Finance and Administrative Sciences. ISSN 1450-2275. Issue 31. 82-87.

Amelia, Anisah.2010. Pengaruh Work To Family Conflict dan Family To Work Conflict Terhadap Kepuasan Dalam Bekerja, Keinginan Pindah Tempat Kerja, dan Kinerja Karyawan. Jam (4), (3), 201-219.

Ariani, S., Lalu S.,and Agusdin. 2017. Pengaruh Konflik Pekerjaan-Keluarga (Work Family Conflict) Dan Beban Kerja Terhadap Stres Kerja Dan Kinerja Bendahara Wanita Dinas Pekerjaan Umum Kabupaten/ Kota Se Pulau Lombok). Jurnal Magister Manajemen Universitas Mataram, (6), (1), 1-20.

Asfahyadin, L.A., Nofal, N., Muh, T., Gusli, T.S., Rosmawaty., Kartini., and Mirad. 2017. The Influence Of Work Family Conflict And Work Stress On Employee Performance. International Journal of Management and Applied Science, (3), (2), 1-6.

Astianto, Anggit and Heru Suprihhadi. 2014. Pengaruh Stres Kerja Dan Beban Kerja Terhadap Kinerja Karyawan Pdam Surabaya. Jurnal Ilmu Dan Riset Manajemen, (3), (7), 1-17.

Asvita, Adil. 2015. Work-Family Conflict: Pengaruh Langsung Dan Tidak Langsung Terhadap Job Performance Dan Moderasi Self-efficacy 
Perawat Unit IRD RSUD Dr. Soetomo, Surabaya. Thesis. Program Studi Magister Sains ManajemenFakultas Ekonomi Dan Bisnis,Universitas Airlangga.

Aqeel,Ahmad and Sher Afgan. 2016. The Relationship of job stres and turnover intention on commercial bank of Pakistan by assering the mediating role of burnout. Journal Of Business Strategies, (10), (1), 1-23.

Bashir, Usman and Muhammad Ismail Ramay. 2010. Impact of Stress on Employees Job Performance A Study on Banking Sector of Pakistan. International Journal of Marketing Studies, (2), (1), 122-126.

Bazana, S.,and Dodd. 2013. Conscientiousness, Work Family Conflict And Stress Amongst Police Officers InAlice, South Africa. Journal of Psychology, (4), (1), 1-8.

Boles James S, W. Gary Howard \& Heather Howard Donofrio. 2001. An Investigation Into The Inter-Relationships of Work Family Conflict, Family-Work Conflit and Work Satiscaftion. Journal of Managerial Issues, (13), (3), 376-390.

Carlson, D.S., K. Michele Kacmar., and Larry J. Williams. 2000. Construction and Initial Validation of a Multidimensional Measure of Work-Family Conflict. Journal of Vocational Behavior (56), (2),249-276.

Chen,. Mei-Fang,. Chieh-Peng Lin., and Gin-Yen Lien. 2011. Modelling job stres as a mediating role in predicting turnover intention. The Service Industries Journal, (32), (8), 1327-1345.

Choi, S.L., Tan, O.K., Teoh, A.P.,and Rajendran Muthuveloo. 2014. Investigation on the Impact of Job Stresors on Nurses in Malaysia. Asian Social Scienc,(10), (4), 67-77.

Cynthia, J.P., Vasanthee, G., Zubeda, P.,and Sarojini Ramgoon. 2006. Working Mothers: Family-Work Conflict, Job Performance And Family/Work Variables. Journal Of Industrial Psychology, (32), (2), 39-45.

Darcy, Coletteand Alma McCarthy.2007. Work Family Conflict An Eploration of the differential effects dependent child's age on working parents. Journal of European IndustrialTraining, (31), (7), 530-549.

Dewi, C.N.C., I Wayan Bagia and Gede, P.A.J.S. 2014. Pengaruh Stres Kerja Dan Kepuasan Kerja Terhadap Kinerja Karyawan Pada Bagian Tenaga Penjualan Ud Surya Raditya Negara. E-Journal Bisma Universitas Pendidikan Ganesha Jurusan Manajemen (Volume 2 Tahun 2014). 
Dewi, Cokorda Istri Ari Sintya. 2016. Pengaruh Stres Kerja Dan Motivasi Kerja Terhadap Kinerja Karyawan Pada Pt. Bank Bpd Bali Cabang Ubud. EJurnal Manajemen Unud, (5), (12), 7583-7606.

Dhanabhakyam, Dr. M \& J. Malarvizhi. 2014. Work-Family Conflict and Work Stress among Married Working Women In Public and Private Sector Organizations. International Journal Of Business and Mangement, (7),(10),46-52.

Divara, I.G.A.G.K., andAgoes Ganesha Rahyuda. 2016. Pengaruh Work Family Conflict Terhadap Stres Kerja Dan Komitmen Organisasional Pegawai Kontrak Dinas Kebudayaan Provinsi Bali. E-Jurnal Manajemen Unud, (5), (11), 6994-7021.

Drach-Zahavy, A. 2004. Nursing and healthcare management andpolicy Primary nurses performance: role of supportive management.Journal of Advanced Nursing, (45), (1), 7-16.

Evans, L. (2002). An exploration of distict nurses' perception of occupational stress. British Journal of Nursing, (11), (8), 576-585.

Ferdinand, Augusty. 2014. Metode Penelitian Manajemen. Edisi 5. Semarang: Badan Penerbitan Universitas Diponegoro.

Frone, M.R and Marcia Russell. 1992. Antecedents and Outcomes of Work Family Conflict: Testing a Model of the Work Family Interface. Journal of Applied Psychology,(77), (1), 65-78.

Gibson, Ivancevich. 1997. Organisasi : Perilaku , Truktur. Jakarta: Binarupa Aksara.

Gibson, J.L. 2003. Struktur Organisasi dan Manajemen. Jakarta: Erlangga.

Gutek, B. A., Searle, S., and Klepa, L. 1991. Rational versus gender role explainations for work family conflict. Jurnal of Applied Psychology, (76), (4), 560-568.

Greenhaus, J.H. and Nicholas J. Beutell. 1985. Sources of Conflict Between Work and Family Roles1. Academy of Management Review. (10), (1), 76-88.

Hammer, TH., PO., Saksvik, K. Nytro., H. Torvatn and M. Byazit. 2004. Expanding the psychosocial work environment: workplace norms and work family conflict as correlates of stress and health. Journal of occupational health psychology, (9), (1), 83-97.

Handoko, T.H. 2011. Manajemen Personalia dan Sumber Daya Manusia. Edisi Kedua. Cetakan ke18. Yogyakarta: BPFE. 
Harsono, A.R., and Tri Maryati. 2013. Pengaruh Konflik Peran Ganda Terhadap Kinerja Pegawai Wanita Dengan Stres Kerja Sebagai Variabel Pemediasi Di Dinas Pendapatan Pengelolaan Keuangan Dan Aset Kabupaten Kulon Progo. (4),(1)| Jbti, 1-30.

Hasibuan, Malayu S.P. 2009. Manajemen Personalia. Yogyakarta: BPFE.

Hasibuan, Malayu S.P. 2006. Manajemen Sumber Daya Manusia. Jakarta: Budii Aksara.

Hermayanti, Desy. 2014. Kebermaknaan hidup dan konflik peran ganda pada wanita karier yang berkeluarga di kota samarinda. eJournal Psikologi, (2), (3), 269-278.

Hidayati, R., Yadi, P.,and Susatyo Yuwono. 2008. Kecerdasan Emosi, Stres kerja dan Kinerja Karyawan. Jurnal Psikologi, (2), (1) 91-98.

Hui-Ying, Tsai. 2008. Work-Family Conflict, Positive Spillover, And Emotions Among Asian American Working Mothers. A Dissertation. Doctor Of Philosophy, University Of Michigan.

Ingan, Ukur br Sitepu. 2014. Manajemen Dan Keterampilan Kinerja Pegawai Pada Asuransi Jiwa XXX. Jurnal Saintech, (06), (2), 54-58.

Indriyani, Azazah. 2009. "Pengaruh Konflik Peran Ganda Dan Stres Kerja Terhadap KinerjaWanita perawat Rumah Sakit". Thesis. Program StudiMagisterManajemenProgram

PascasarjanaUniversitasDiponegoroSemarang.

Irianto, Yusuf. 2001. Manajemen Sumber Daya Manusia : Teori dan Praktek. Surabaya : Insan Cendikia.

Irviana, Lala. 2016. Mediation Role Emotional Exhaustion To The Relationship Between Work-Family Conflicts And Job Performance. Jurnal Bisnis \&Ekonomi , (14), (2), 95-109.

Iqbal, Muhammad. 2016. Pengaruh Konflik Peran Ganda Dan Stres KerjaTerhadap Kinerja Pegawai WanitaPada Rumah Sakit Umum Daerah Menggala. Thesis. Universitas Lampung.

Jackson and Yohanes Arianto. 2017. Pengaruh Work Family Conflict Terhadap Kinerja Karyawati PT Sinta Pertiwi. Jurnal Kreatif : Pemasaran, Sumberdaya Manusia Dan Keuangan, (5), (1), 99-111.

Joy, E.P., andLeah Ruppanner. 2012. Work-To-Family And Family-To-Work Spillover: The ImplicationsOf Childcare Policy And Maximum WorkHour Legislation. J Fam Econ Iss (33), 283-297. 
Karabaya, M.E., Bulent, A., and Meral elci. 2013. Effects of Family-Work Conflict, Locus of Control, Self Confidence and Extraversion Personality on Employee Work Stress. Procedia - Social and Behavioral Science,(235), (2016), $269-280$.

Karakaş, A. and Şahin (2017), “The Relation between Work Family Life Conflict, Job Performance and Job Stress: A Research on Hotel Employee", Sosyoekonomi, (25), (32), 51-69.

Karatepe, O.M., and Kilic, H. 2007. Relationships of supervisor support and conflicts in the work-family interface with the selected job outcomes of frontline employees. Tourism Management, (28), 238-252.

Karimi, Roohangiz and Farhad Alipour. 2011. Social support and job stres: moderating role of locus of control. Journal of Asian Scientific Research, (1), (6), 285-290.

Kazmi, S.S.A., Muhammad, H., Mehboob, U., Syeikh,R.M., and. Muhammad,A.K. 2017. Impact Of Job Stress On Work Family Conflict: A Case Study Of Bankers Of Private Sector Banks In Peshawar, Pakistan. City University Research Journal Special Issue: AIC, Malaysia PP 195-205.

Kim, J. L. S. and Ling, C. S. 2001. Work-Family Conflict of Women Entrepreneurs in Singapore. Women in Management Review, (16),204221.

Kirkcaldy, B. D., and Martin, T. (2000). Job stress and satisfaction among nurses:individual differences. Stress Medicine, (16), (2), 77-89.

Khatibi, A., Asadi and Hamidi. 2009. The Relationship Between Job Stress and Organizational Commitment in National Olympic and Paralympic Academy. World Journal of Sport Sciences, (2), (4), 272-278.

Lalu,S.E.L., and. Lapian. 2016. Analyzing The Effect Of Work Life Conflict and Job Stress on Employee Performance (Study At The Main Office Of PT. Bank Sulutgo). Jurnal EMBA (4) ,(1), 1147-1155.

Lu. Yong., Xiao-Min Hu., Xiao-Liang Huang., and Xiao-Dong Zhuang. 2017. The relationship between job satisfaction, work stress, work- family conflict, and turnover intention among physicians in Guangdong, China: a cross-sectional study. BMJ Open 2017;7:e014894. doi:10.1136/ bmjopen-2016-014894.

Mai Ngoc Khuong and Vu Hai Yen. 2016. Investigate the Effects of Job Stres on Employee JobPerformance - A Case Study at Dong Xuyen Industrial 
Zone, Vietnam. International Journal of Trade, Economics and Finance, (7), (2), 31-37.

Muamarah Hanik Susilawati and Indra Wijaya Kusuma. 2012. Pengaruh iklim etis organisasi dan setres kerja terhadap keinginan berpindah dengan kepuasan kerja sebagai variabel intervening (studi pada account representative dan pemeriksaan pajak di kantor pelayanan pajak di pulau jawa). Jurnal BPPK, (5) Hal. 77-79.

Nabirye, Rose Chalo.2010. Occupational Stres, Job Satisfaction, And Job Performance Among Hospital Nurses In Kampala, Uganda. A Dissertation. University of Alabama at Birmingham, in partial fulfillment of the requirements for the degree of Doctor of Philosophy.

Nart Senemand Ozgur Batur. 2013. The relation between work-family conflict, job stres, organizational commitment and job performance: A study on turkish primary teachers. European Journal of Research on Education, (2), (2), 72-81.

NataliaPutri and Suharnomo. 2015. Analisis Pengaruh Work Family Conflict DanAmbiguitas Peran Terhadap Kinerja KaryawanDengan Stress Kerja Sebagai Variabel Intervening(Studi Pada Karyawan Wanita Bagian Produksi Pt. Nyonya MeneerSemarang). Diponegoro Journal Of Management, (4), (2), 1-13.

Naithani, P. (2010). "Overview of Work-Life Balance Discourse and its Relevance in Current Economic Scenario." Asian Social Science,6: 148155.

Noe, Raymond A, John R. Holenbeck, Barry Gerhart and Patrick M. Wright. 2011. Manajemen Sumber Daya Manusia, Mencapai Keungguln Bersaing, Buku 1, Edisi 6. Jakarta: Salemba Empat.

Nurnazirah,J., Samsiah, M., Zurwina, S., and Fauziah Noordin. 2015. Work Family Conflict and Stres: Evidence from Malaysia. Journal of Economics, Business and Management, (3), (2), 309-312.

Nurqamar, Insany Fitri, Siti Haerani, \& Ria Mardiana.2014.Role Conflict and Role Ambiguity : The Implication Of Occupational Stress and Performance Of Studies Program's Structural Officer. Jurnal Analisis, (3), (1), 24-31.

Noor, N.N., Kusdi, R., and Ika Ruhana. 2016. Pengaruh Stres Kerja dan Kepuasan Kerja Terhadap Kinerja Karyawan (Studi Pada Karyawan PT. Jasa Raharja (Persero) Cabang Jawa Timur di Surabaya). Jurnal Administrasi Bisnis, (31), (1), 9-15. 
Novianti, Nur Pratiwi. 2015. Correlation between Work-Family Conflict and Job Stress among Government Public Service Employees: The Moderating Role of Psychological Capital. Journal of Psychology (JPsych) (3), (1), $1-6$.

Parasuraman, S., Jeffrey, H.G., and Cherlyn,S.G. 1992. Role Stressors, social support, and well being among two career copules. Journal of Organizational Behavior, (13), (4), 339-356.

Patrice L. Esson. 2004. Consequences Of Work Family Conflict: Testing A New Model Of Work Related, Non Work Related And Stres Related Outcomes. Thesis. Faculty of The Virginia Polytechnic Institute and State University.

Patricia R. DeLucia, Tammy E. Ott, \& Patrick A. Palmieri. 2017. Performance in Nursing. (https://www.researchgate.net/publication/245026223).

Preacher, K. J. and Andrew F.H. 2004. Spss And Sas Procedures For Estimating Indirect Effects In Simple Mediation Models. Behavior Research Methods, Instruments, \& Computers (36), (4), 717-731.

Radzali,F.M., Aminah, A., and Zoharah Omar. 2013. Workload, Job Stress, Family-To-Work Conflict and Deviant Workplace Behavior.International Journal of Academic Research in Business and Social Sciences, (3), (12), 109-115.

Raharjo, Slamet. 2009. Konflik Pekerjaan Keluarga (Work Family Conflict), Stres Kerja dan Pengaruh Kinerja Pelayanan Konsumen (Studi Kasus Pada PT. Bank Mandiri (Persero) Tbk Wilayah Surakarta). Tesis. Program Studi Magister Manajemen Program Pascasarjana Universitas Sebelas Maret Surakarta.

Rajak, Adnan. 2013. Pengaruh Konflik Interpersonal, Work-Family Conflict Dan Stres, Terhadap Kepuasan Kerja Dan Dampaknya Terhadap Kepuasan Hidup. Jurnal Siasat Bisnis (17) ,(2), 131-156.

Retnaningrum,A.K.,and Mochammad, Al Musadieq. 2016. Pengaruh WorkFamily Conflict Terhadap Kepuasan Kerja Dan Kinerja (Studi Pada Wanita perawat Rsud Wonosari Yogyakarta). Jurnal Administrasi Bisnis $(\mathrm{Jab}) \mid$, (36), (1), 72-81.

Riandy. 2016. Pengaruh Stres Kerja Terhadap Kinerja Karyawan Pada PT. Borneo Laboratorium Inspeksi Dan Surveyor Service Di Samarinda. eJournal Administrasi Bisnis, (4), (4), 1059-1072. 
Riduwan and Engkos Achmad Kuncoro. 2012. Cara Menggunakan dan Memakai Path Analysis (Analisis Jalur). Cetakan Keempat. Bandung : Alfabeta.

Riduwan. 2013. Metode dan Teknik Menyusun Tesis. Cetakan Kesembilan. Bandung : Alfabeta.

Risma, Devi. 2012. Pengaruh kecerdasan emosional terhadap kinerja karyawan: penelitian eksperimen, Educhild, (01), (1), 86-97.

Rivai Veithzal and Jauvani Sagala. 2004. Manajemen Sumber DayaManusia Untuk Perusahaan, Dari Teori ke Praktik. Jakarta: Raja Grafindo Persada.

Robbins, Stephen dan Judge, Timothy. 2008. Perilaku Organisasi (Organizational Behavior). Jakarta: Salemba Empat.

Roboth Jane Y. 2015.Analisis Work Family Conflict, Stres Kerja Dan Kinerja Wanita Berperan Ganda Pada Yayasan Compassion East Indonesia. Jurnal Riset Bisnis dan Manajemen (3) ,(1), 33-46.

Ruswanti Endang and Ostevi Adolfin Jacobus. 2013. Konflik Antara Pekerjaan Dan Keluarga, StresKerja Terhadap Kinerja Wanita perawat PadaRumah Sakit Bethesda Yogyakarta. Forum Ilmiah (10), ( 1), 81-89.

Siagian, Sondang P.2008. Manajemen Sumber Daya Manusia. Jakarta: Bumi Aksara.

Siregar. J.P and Amalia. 2003. Farmasi Rumah Sakit : Teori dan Penerapan. Jakarta : EGC.

Siu, O. I. 2003. Job stres and job performance among employees in Hong Kong: The role of Chinese work values and organizational commitment. International Journal of Psychology, (38), (6), 337-347.

Sudarmanto. 2009. Kinerja dan Pengembangan Kompetensi Sumber Daya Manusia (Teori Dimensi Ppengukuran dan Implementasi dalam Organisasi). Yogyakarta: Pustaka Pelajar.

Sugiyono. 2013. Metode Penelitian Bisnis. Cetakan ke-17. Bandung: Alfabeta.

Suparyadi, H. 2015. Manajemen Sumber Daya Manusia - Menciptakan Keunggulan Bersaing Berbasis Kompetensi SDM. Edisi 1. Yogyakarta: Andi.

Suryani, Ni Kadek, I Wayan Gde Sarmawa and Made Wardana. 2014. Work Family Conflict, Jobstress And Job Performance (Case Study Spa 
Employee In Bali). European Journal Of Business And Management, (6), (32), 189-195.

Tewal, BernhardandFlorensia B.T. 2014.Pengaruh Konflik Peran Terhadap Kinerja Wanita Karir Pada Universitas Sam Ratulangi Manado. Jurnal Emba, (2), (1), 450-456.

Timpe, A. Dale. 2002. Kinerja Sari Ilmu dan Segi Manajemen Bisnis. Jakarta: Elex Media Komputindo.

Thomas, Linda Thiede and Daniel C. Ganster. 1995. Impact of Family-Supportive Work Variables on Work-Family Conflict and Strain: A Control Perspective. Journal of Applied Psychology, (80), (1) ,6-15.

Verma, Vimla. 2013. Work Family Conflict. Indian Journal of Health and Wellbeing, (4), (3), 644-649.

Wai Chia Kang, Tan Gay May, Ter Shin Ye,Toh Shu Yuan\&Yap Yee Mun.2013. The Relationship Between Work Stress And Auditors Job Performance. Disertation.Faculty of Business and Finance Departement of Accounting. Univeriti Tunku Abdul Rahman.

Wibowo, Bayu Arifianto \& Edy Rahardja. 2015. Pengaruh Kelelahan Kerja Dan Konflik PeranTerhadap Kinerja Karyawan Dengan Stress KerjaSebagai Variabel Intervening(Studi Pada Karyawan Rsud Ra Kartini Jepara), Diponegoro Journal Of Management,(4), (1), 1-11.

Yildirim, D., Aycan, Z. 2008. Nurses' work demands and work-family conflict: A questionnairesurvey, International Journal of Nursing Studies, (doi:10.1016/j.ijnurstu.2007.10.010)

Yozgat, Ugur. Assoc. Serra Yurtkoru and Elif Bilginoglu. 2013. Job stres and job performance among employes in public sector in Istanbul: examining the moderating role of emotional intelligence. Social and Behavior Sciences, (75), 518-524.

Zeb, Alam., Gouhar, S., and Shafiqur, R. 2015. The Impact Of Job Stress On Employee's Performance: Investigating The Moderating Effect Of Employees Motivation. City University Research Journal, (5), (1), 120129. 